\title{
Modelling the Drying Characteristics and Kinetics of Hot Air-Drying of Unblanched Whole Red Pepper and Blanched Bitter Leaf Slices
}

\author{
Samuel Enahoro Agarry* \\ Department of Chemical Engineering, Delta State University, Abraka, Oleh Campus, Nigeria \\ A R T I C LE IN F O \\ Research Article \\ Received 04 May 2016 \\ Accepted 17 January 2017 \\ Keywords: \\ Red pepper \\ Bitter leaf \\ Oven drying \\ Mathematical modelling \\ Effective moisture diffusivity \\ "Corresponding Author: \\ E-mail: sam_agarry@yahoo.com \begin{abstract}
A B S T R A C T
The objective of this study was to investigate the drying characteristics and kinetics of red pepper and bitter leaf under the influence of different drying temperatures. The drying experiments were carried out at dry bulb temperature of $35,45,55$ and $75^{\circ} \mathrm{C}$, respectively in an oven dryer. The results showed that as drying temperature increased, drying rate also increased and the drying time decreased. It was observed that un-sliced red pepper and sliced bitter leaf would dry within $2.5-12 \mathrm{~h}$ and $1.67-7 \mathrm{~h}$, respectively at temperature ranging from 75 to $35^{\circ} \mathrm{C}$. The drying of red pepper and bitter leaf was both in the constant and falling rate period. Four semi-empirical mathematical drying models (Newton, Page, Henderson and Pabis, and Logarithmic models) were fitted to the experimental drying curves. The models were compared using the coefficient of determination $\left(R^{2}\right)$ and the root mean square error (RMSE). The Page model has shown a better fit to the experimental drying data of red pepper and bitter leaf, respectively as relatively compared to other tested models. Moisture transport during drying was described by the application of Fick's diffusion model and the effective moisture diffusivity was estimated. The value ranges from 15.69 to $84.79 \times 10^{-9} \mathrm{~m}^{2} / \mathrm{s}$ and 0.294 to $1.263 \times 10^{-9} \mathrm{~m}^{2} / \mathrm{s}$ for red pepper and bitter leaf, respectively. The Arrhenius-type relationship describes the temperature dependence of effective moisture diffusivity and was determined to be $37.11 \mathrm{~kJ} / \mathrm{mol}$ and $32.86 \mathrm{~kJ} / \mathrm{mol}$ for red pepper and bitter leaf, respectively. A correlation between the drying time and the heat transfer area was also developed.
\end{abstract}

\section{Introduction}

Fruits and vegetables are not steadily supplied throughout the year. They are very abundant immediately after the rains, becomes scarce late in the rainy season and more so in the dry season (Ihekoronye and Ngoddy, 1985). However, during peak periods these fruits and vegetables are destroyed due to spoilage caused by the activity of microorganisms such as yeast, mould, bacteria, the conditions favourable to their propagation being moisture and warmth. In addition, they may be attacked by insects, rodents and enzymes (Maudkordylas, 1990). Thus there are considerable damage, wastage and losses of these seasonal fruits and vegetables due to lack of proper processing and preservation in many countries, which has been estimated to be $30-40 \%$ in developing countries (Karim and Hawlader, 2005; Afolabi and Agarry, 2014). The need to reduce post-harvest damage, wastage and losses is of paramount importance for these countries. To overcome this situation, there is the need after harvest to preserve these fruits and vegetables by checking their enzyme action as well as remove the moisture content to a certain level to prevent the growth of mould and bacterial action. Some of the primary methods of fruits and vegetables preservation include controlled atmosphere storage, freezing, salting, fermentation, irradiation, pasteurization and dehydration (drying) (Maudkordylas, 1990). One of the most widely used methods of vegetables preservation is drying so as to extend their shelf-life.

Drying is therefore of great antiquity as a form of preservation (Barnell, 1974) and is gaining forces as one of the promising techniques and thus become an object for research studies. It is defined as a moisture removal process due to simultaneous heat and mass transfer (Waewsak et al., 2006; Afolabi and Agarry, 2014). Therefore, the drying of fruits and vegetables is of paramount importance as they are considered to offer the most rapid and lowest cost method of providing adequate supplies of vitamins, minerals and fibres for mankind. The traditional way of drying these vegetables has been by open sun drying, however, this is not always suited to large-scale production due to lack of ability to control the drying conditions, the uncertainties of ambient conditions, large area requirements, contamination of dust and insect and rodent infestation, low product quality, destruction of vitamins, flavours and colour, caramelized and crusted pieces produced and sour taste present in dried products (Ertekin and Yaldiz, 2004). Therefore, to avoid these problems, drying equipment were designed and produced on the basis of drying test. The studies based on simulation models are needed for design and operation of 
dryers as well as useful in improving the existing drying system.

Thus, several research workers in recent times have investigated the drying characteristics of different vegetables using different drying methods such as open sun drying for onion slices (Arslan and Ozcan, 2010); solar drying for green pepper (Akpinar and Bicer, 2008) and okra (Doymaz, 2011; Ismail and Ibn Idriss, 2013)); and hot air drying for red pepper (Simal et al., 2005), okra (Doymaz, 2005; Lemus-Mondaca et al., 2015) and tomato (Doymaz, 2007; Agarry, 2016), respectively. Many mathematical drying models have been proposed to describe the drying characteristic of these fruits and vegetables (Yaldiz et al., 2001; Akpinar et al., 2003; Afolabi and Agarry, 2014; Agarry, 2016). Few reliable simulation models that considered equipment model to aid in the design of batch dryers for fruits have been proposed (Karim and Hawlader, 2005; Afolabi and Agarry, 2014). Nonetheless, more drying models based on heat and mass transferred from the material to the drying medium which can predict accurately the drying kinetics of the agricultural product is often needed. This type of model can be used as a design tool for batch tray dryer. In this study, a simulation/correlation model describing simultaneous heat and mass transfer processes is proposed to describe the drying potential of vegetables. The model takes the heat drying surface area of the equipment during drying into consideration.

The objectives of this study are to investigate the drying characteristics and kinetics of both red pepper and bitter leaf with respect to variation in drying temperature under forced convection (oven drying); to model the drying kinetics by application of known semi-empirical mathematical drying models in the literature and to develop a mathematical correlation between the drying time and the heat transfer area.

\section{Materials and Method}

\section{Blanching Pretreatment}

Fresh bitter leaves were thoroughly washed and then blanched in hot water at $80^{\circ} \mathrm{C}$ for $5 \mathrm{~min}$. They were then cut into pieces and washed again to reduce the bitter taste. However, the red peppers were neither blanched nor sliced.

\section{Oven Drying}

The drying experiments were carried out using an electric oven dryer (Herans Type by Karl Kobb Scientific Technical Supplies, Buchschlag Frankfurt, West Germany). The drying test procedure was carried out as follows: Approximately $100 \mathrm{~g}$ of un-blanched whole red peppers as well as $100 \mathrm{~g}$ of sliced blanched bitter leaves were separately dried at four different dry bulb temperatures of $35,45,55$ and $75^{\circ} \mathrm{C}$. At one hour interval, samples were withdrawn from the dryer, allowed to cool in a desiccator, and weighed until approximately $100 \%$ (dry weight basis (d.b)) final moisture content was obtained. However, at $75^{\circ} \mathrm{C}$, the weight was taken at 30 min interval. The moisture content of both the fresh and dried samples was determined according to AOAC (1995). The drying rate of the samples was calculated based on weight of water removed per unit time and per kilogram of dry matter (solid) and expressed in units of $\mathrm{kgkg}^{-1} \mathrm{~h}^{-1}$ (Agarry et al., 2006).

\section{Mathematical Modelling}

Drying models describe the drying phenomenon in a unified way regardless of the controlling mechanisms (Kingsly et al., 2007; Afolabi and Agarry, 2014). In thin layer drying, the moisture ratio during drying can be calculated according to Eq. (1) (Agarry and Aworanti, 2012; Afolabi and Agarry, 2014):

$$
M R=\frac{M-M_{e}}{M_{0}-M_{e}}
$$

Where MR is the dimensionless moisture ratio, $M$, the average moisture content at time $t, M_{0}$, the initial moisture content, and $M_{e}$, the equilibrium moisture content respectively, on a dry weight basis.

During the hot air-drying of whole red pepper and bitter leaf slices in an oven dryer, the samples were continuously not exposed to uniform relative humidity and temperature. As a result of this, the equilibrium moisture content could not be determined and since this is usually not high for food materials, the equilibrium moisture content was assumed to be zero (Waewsak et al., 2006; Agarry and Owabor, 2012; Agarry and Aworanti, 2012; Afolabi and Agarry, 2014). Hence, the moisture ratio (Eq. 1) was simplified according to Pala et al. (1996) and Kingsly et al. (2007) to:

$$
M R=\frac{M}{M_{0}}
$$

The recorded moisture contents for each vegetable sample were then used to plot the drying curves. Four known semi-empirical mathematical drying models that expresses relationship between moisture ratio (MR) and the drying time, $\mathrm{t}$ as presented in Table 1 were applied to the drying curves obtained for each sample at each drying temperature.

Table 1 Semi-empirical drying models

\begin{tabular}{l|ll}
\hline \multicolumn{1}{c|}{ Model Names } & \multicolumn{1}{c}{ Model Equation } & $\begin{array}{c}\text { Eq. } \\
\text { Number }\end{array}$ \\
\hline Newton & MR $=\exp (-\mathrm{kt})$ & $(3)$ \\
Page & $\mathrm{MR}=\exp \left(-\mathrm{kt}^{\mathrm{n}}\right)$ & $(4)$ \\
Henderson and Pabis & $\mathrm{MR}=\mathrm{a} \exp (-\mathrm{kt})$ & $(5)$ \\
Logarithmic & $\mathrm{MR}=\mathrm{a} \exp (-\mathrm{kt})+\mathrm{c}$ & $(6)$ \\
\hline $\begin{array}{l}\text { a,c,n, empirical constants; } \mathrm{k}, \text { drying constant; t, drying time; MR, } \\
\text { moisture ratio. }\end{array}$
\end{tabular}

Non-linear regression analysis was used to select the best model (based on the quality of fit) that describes the drying characteristics. Some of these models are recently used for determination of moisture ratio with drying time by Ismail and Ibn Idriss (2013), Khawas et al. (2014) and Afolabi and Agarry (2014). 
The non-regression analysis was performed using MATLAB computer software package (version 6.5). The coefficient of determination $\left(R^{2}\right)$ and root mean square error (RMSE) were major criteria for selection of the best model equation to describe the drying curve. For quality fit, $R^{2}$ value should be high and RMSE should be low (Demir et al., 2004; Agarry and Owabor, 2012; Afolabi and Agarry 2014). In order to evaluate the goodness of fit of the simulation provided by the proposed (best selected) model, different statistical parameters are usually used. In this study, the mean relative error (Eq. 7) and root mean square error (Eq. 8) (Nguyen et al., 2004; Simal et al., 2005; Agarry and Owabor, 2012; Afolabi and Agarry 2014) were calculated.

$$
\begin{aligned}
& \% E=\frac{100}{N} \sum_{i=1}^{N}\left[\frac{M R_{\text {expi }}-M R_{\text {prei }}}{M R_{\text {expi }}}\right] \\
& R M S E=\left[\frac{1}{N} \sum_{i=1}^{N}\left(M R_{\text {expi }}-M R_{\text {prei }}\right)^{2}\right]^{\frac{1}{2}}
\end{aligned}
$$

Where $\mathrm{N}$, total number of observations, $M R_{\text {exp } i}$ experimental moisture ratio values and $M R_{\text {prei }}$, predicted moisture ratio values. These modules have been used in the literature to evaluate the goodness of fit of different mathematical models (Agarry and Aworanti, 2012; Afolabi and Agarry, 2014).

\section{Effective Moisture Diffusivity}

In the determination of the effective moisture diffusivity $\left(D_{e f f}\right)$, a mathematical model was used based on Fick's second law of diffusion which expresses a relationship between MR and $D_{\text {eff }}$ (Agarry and Aworanti, 2012; Afolabi and Agarry, 2014). The whole red pepper and bitter leaf slices are assumed in the form of spherical and the Fick's second law of diffusion for spherical object is defined as follow (Afolabi and Agarry, 2014):

$$
\frac{\partial m}{\partial t}=D_{e f f}\left[\frac{\partial^{2} m}{\partial r^{2}}+\frac{2}{r} \frac{\partial m}{\partial r}\right]
$$

Where $m$ can be defined as the moisture content (dry or wet basis), moisture ratio, weight ratio and density. By using the appropriate initial and boundary conditions and the assumptions of independence of diffusivities and temperature from interior moisture content, negligible volume shrinkage, and discounting the resistance of external convective mass transfer, Crank (1975) gave the analytical solution to Eq. (9) for object with spherical geometry as (Ochoa-Martinez and Ayala-Aponte, 2009; Afolabi and Agarry, 2014):

$$
M R=\frac{6}{\pi^{2}} \sum_{n=1}^{\infty} \frac{1}{n^{2}} \exp \left(\frac{-n^{2} \pi^{2} D_{e f f} t}{r^{2}}\right)
$$

Where $D_{\text {eff }}$ is effective moisture diffusivity $\left(\mathrm{m}^{2} / \mathrm{s}\right), \mathrm{t}$, drying time and $r$, radius of the spherical object $(\mathrm{m})$. To be able to determine the $D_{\text {eff }}$, Eq. (10) may be simplified to a linear logarithmic form (Eq. 11) (Feng, 2000; Afolabi and Agarry, 2014):

$$
\ln M R=\ln \left(\frac{6}{\pi^{2}}\right)-\left(\frac{\pi^{2} D_{e f f} t}{r^{2}}\right)
$$

The relationship between the $D_{\text {eff }}$ and temperature is assumed in the Arrhenius form of the type (Afolabi and Agarry, 2014):

$$
D_{e f f}=D_{0} \exp \left[\frac{-E_{a}}{R T_{a b s}}\right]
$$

Where $D_{0}$ is the pre-exponential factor of the Arrhenius equation $\left(\mathrm{m}^{2} / \mathrm{s}\right), E_{a}$ is the activation energy $(\mathrm{kJ} / \mathrm{mol}), R$ is the universal gas constant $(\mathrm{kJ} / \mathrm{mol} \mathrm{K})$, and $T_{a b s}$ is the absolute temperature $(\mathrm{K})$. Taking the natural logarithm of both sides, the above exponential form of Arrhenius can be transformed into a linear logarithmic form, Eq. (13) (Afolabi and Agarry, 2014):

$$
\ln D_{e f f}=\ln D_{0}-\left(\frac{E_{a}}{R}\right) \frac{1}{T_{a b s}}
$$

Consequently, $E_{a}$ can be obtained from the linear plot of $\ln D_{e f f}$ vs $1 / T_{a b s}$.

\section{Results and Discussion}

The drying kinetics of whole red pepper and bitter leaf slices were respectively determined at different bulb temperature under oven drying for average moisture contents from $809 \%$ d.b to $100 \%$ d.b ( $\mathrm{kg}$ water $/ \mathrm{kg}$ dry matter). This shows that diffusion is most likely the predominant physical mechanism governing moisture transport within the whole un-sliced red pepper and bitter leaf, respectively. Similar observations have been reported by Akpinar and Bicer (2008) for long green pepper, Doymaz (2005), Sobukola (2009) and Ismail and Ibn Idriss (2013) for okra, Doymaz (2007) for tomatoes, Tunde-Akintunde and Afon (2010) for cassava, and Agarry and Owabor (2012) for banana.

The initial drying rates for whole un-sliced red pepper and bitter leaf were generally faster. These observations may be due to the higher initial moisture content of the whole un-sliced red pepper and bitter leaf, respectively. Figure 1 shows the dependence of moisture content on drying time for whole red pepper and bitter leaf slices at different temperature.

As expected for drying at different temperature, moisture content dropped dramatically in the early drying stage, encompassing about one fourth of the overall time, and eventually changed little when close to a product moisture content of about $5 \%$ (wet basis) or $100 \%$ (d.b) for whole red pepper (Figure 1(a)) and 4\% (wet basis) or 100 (dry basis) for bitter leaf slices (Figure 1(b)). That is, when the temperature of drying increased, the product moisture content decreased or fell while the amount of moisture removed increased. Initially, the abundance of free water on the product surface contributed to effortless moisture liberation. However, it might become much more difficult to expel water afterwards, when the product surface becomes harder due to shrinkage. Thus, it could be observed from Figure 1(a) and (b) that drying time 
decreased with increase in drying temperature due to higher moisture reduction in samples at a higher temperature. The drying time ranges between 2.5 to $12 \mathrm{~h}$ for un-sliced whole red pepper and 1.67 to $7 \mathrm{~h}$ for sliced bitter leaf, respectively. Figure 2 (a) and (b) shows the various drying curves for whole red pepper and bitter leaf slices which consisted of drying rates at different temperature plotted against their corresponding product moisture content.

It is observed that the respective product moisture content of red pepper (Figure 2a) and bitter leaf (Figure 2b) varies constantly with the rate of drying followed by linear variation at $45^{\circ} \mathrm{C}, 55^{\circ} \mathrm{C}$ and $75^{\circ} \mathrm{C}$ respectively. However, for red pepper at $35^{\circ} \mathrm{C}$, the variations were purely linear. Hence, the respective drying of whole red pepper as well as that of bitter leaf is both in the constant rate and falling rate period. Thus, red pepper and bitter leaf are both hygroscopic. As seen in Figure 2 (a) and (b), it was also observed that with temperature increase, the drying rate also increased. That is, drying improves with increase in temperature. This was expected as higher temperature implies higher transfer drying force.

\section{Modelling the Drying Kinetics}

Experimental results of moisture variation with drying time were fitted to four different drying models as presented in Table 1. By using the non-linear regression tool of MATLAB 6.5 version computer software package, the different models parameters were determined. The model that provided the highest coefficient of determination $\left(R^{2}\right)$ and the lowest root mean square error (RMSE) was selected. The values of $R^{2}$ and RMSE obtained by the non-linear regression analysis are summarized in Table 2 for whole red pepper and bitter leaf slices dried under oven dryer.

The results in Table 2 show that at different drying temperature, the value of $R^{2}$ was greater than 0.90 , indicating a good fit (Kingsly et al., 2007; Agarry and Aworanti, 2014). However, the $R^{2}$ value for the Page model at the different drying temperature was comparatively the highest and with the lowest RMSE value. Thus, the Page model may be proposed to be the best model to describe the drying behaviour or characteristics of red pepper and bitter leaf, respectively. Similar findings have been reported for hot air drying of red pepper, tomato and potato (Akpinar et al., 2003; Simal et al., 2005; Doymaz, 2007). The estimated values for the Page model parameters are summarized in Table 3. The result showed that under oven drying of whole red pepper and bitter leaf slices described by Page model, the drying constant ' $\mathrm{k}$ ' is higher at a higher drying temperature, while the empirical constant ' $n$ ' is lower at a higher drying temperature. The accuracy of the Page model to simulate the drying curves of red pepper and bitter leaf under oven drying at different drying temperature was respectively evaluated. Figure 3(a - d) and Figure 4(a - d) correspondingly show the representation of the predicted (estimated) vs. experimental moisture ratio of red pepper and bitter leaf during drying through Page model for different drying temperatures.
In order to mathematically evaluate the simulation, the average relative error $(\% \mathrm{E})$ and coefficient of determination $\left(R^{2}\right)$ were calculated from comparing the experimental moisture ratio and those given by the proposed model for the range of drying temperature considered (Agarry and Aworanti, 2012; Afolabi and Agarry, 2014). These results are given in Table 3. From Table 3 , it is observed that the $R^{2}$ values are high and the $\% \mathrm{E}$ values are low for each of the red pepper and bitter leaf samples dried at different drying temperature. Thus, the Page model allowed an accurate simulation of the drying curves of red pepper and bitter leaf for the whole range of temperature studied under oven drying (forced convection); thereby, exhibiting a high concordance between experimental and predicted (estimated) moisture ratio.

Correlation between Drying Time and Heat Surface Area

The equipment used for drying was an electric oven. Therefore, the feed (red pepper and bitter leaf) surface received heat by conduction from the metal tray through the feed and by direct radiation from the hot surface above it. Thus, the drying of the feed was formulated as a boundary value problem described by the generalized one dimensional heat conduction equation.

$$
\frac{\partial T}{\partial t}=\alpha \frac{\partial^{2} T}{\partial Y^{2}}
$$

Hence, a correlation between the drying time and heat transfer area was established

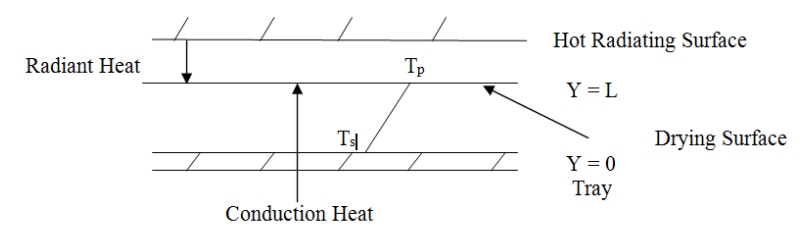

Consider the temperature distribution in a wet or fresh vegetable (feed) y meters thick on the surface of a metal ray inside a drying oven (chamber). The following assumptions were made in line with that made by Audu (1995) but with modifications:

- The physical properties of the feed such as bulk density, heat capacity and thermal conductivity are constant.

- The latent heat of vaporization of free moisture is greater than the heat capacity.

- The heat flux through the metal tray to the drying surface is constant.

- The temperature of the radiating surface is the same as that of the inside surface of the metal tray $\left(\mathrm{T}_{\mathrm{s}}\right)$.

- The temperature distribution is constant and uniform in any plane parallel to the drying surface.

- The drying surface of the feed is exposed to hot radiating surface.

- The heat received by radiation can be expressed as heat transfer coefficient $\left(h_{R}\right)$. 
Table 2 Goodness of fit of the different drying models for red pepper and bitter leaf oven drying data

\begin{tabular}{|c|c|c|c|c|}
\hline Sample & Model & Drying Temperature $\left({ }^{\circ} \mathrm{C}\right)$ & $\overline{\mathrm{R}^{2}}$ & RMSE \\
\hline \multirow{16}{*}{ Red Pepper } & \multirow{4}{*}{ Newton } & 35 & 0.9422 & 0.0815 \\
\hline & & 45 & 0.9648 & 0.0718 \\
\hline & & 55 & 0.9620 & 0.0813 \\
\hline & & 75 & 0.9698 & 0.0644 \\
\hline & \multirow{4}{*}{ Page } & 35 & 0.9856 & 0.0446 \\
\hline & & 45 & 0.9961 & 0.0276 \\
\hline & & 55 & 0.9977 & 0.0244 \\
\hline & & 75 & 0.9989 & 0.0138 \\
\hline & \multirow{4}{*}{ Henderson and Pabis } & 35 & 0.9491 & 0.0837 \\
\hline & & 45 & 0.9678 & 0.0793 \\
\hline & & 55 & 0.9639 & 0.0188 \\
\hline & & 75 & 0.9736 & 0.0673 \\
\hline & \multirow{4}{*}{ Logarithmic } & 35 & 0.9425 & 0.0890 \\
\hline & & 45 & 0.9678 & 0.0793 \\
\hline & & 55 & 0.9639 & 0.0970 \\
\hline & & 75 & 0.9736 & 0.0673 \\
\hline \multirow{16}{*}{ Bitter Leaf } & \multirow{4}{*}{ Newton } & 35 & 0.9688 & 0.0610 \\
\hline & & 45 & 0.9635 & 0.0666 \\
\hline & & 55 & 0.9674 & 0.0584 \\
\hline & & 75 & 0.9568 & 0.0765 \\
\hline & \multirow{4}{*}{ Page } & 35 & 0.9969 & 0.0208 \\
\hline & & 45 & 0.9836 & 0.0450 \\
\hline & & 55 & 0.9798 & 0.0497 \\
\hline & & 75 & 0.9955 & 0.0277 \\
\hline & \multirow{4}{*}{ Henderson and Pabis } & 35 & 0.9744 & 0.0597 \\
\hline & & 45 & 0.9659 & 0.0720 \\
\hline & & 55 & 0.9690 & 0.0615 \\
\hline & & 75 & 0.9619 & 0.0804 \\
\hline & \multirow{4}{*}{ Logarithmic } & 35 & 0.9744 & 0.0597 \\
\hline & & 45 & 0.9659 & 0.0720 \\
\hline & & 55 & 0.9690 & 0.0615 \\
\hline & & 75 & 0.9619 & 0.0258 \\
\hline
\end{tabular}

Table 3 Page model constant parameters and coefficient of determination for drying of red pepper and bitter leaf slices

\begin{tabular}{|c|c|c|c|c|c|}
\hline \multirow{2}{*}{ Sample } & \multirow{2}{*}{ Drying temperature $\left({ }^{\circ} \mathrm{C}\right)$} & \multicolumn{2}{|c|}{ Model Constants } & \multirow{2}{*}{$\mathrm{R}^{2}$} & \multirow{2}{*}{$\% \mathrm{E}$} \\
\hline & & $k \times 10^{-1}$ & $n$ & & \\
\hline \multirow{4}{*}{ Red Pepper } & 35 & 1.9 & 1.532 & 0.9925 & 12.23 \\
\hline & 45 & 5.6 & 1.486 & 0.9960 & 11.84 \\
\hline & 55 & 4.7 & 1.604 & 0.9979 & 13.11 \\
\hline & 75 & 41.1 & 1.446 & 0.9990 & 6.09 \\
\hline \multirow{4}{*}{ Bitter Leaf } & 35 & 11.4 & 1.403 & 0.9970 & 5.55 \\
\hline & 45 & 20.5 & 1.339 & 0.9957 & 24.89 \\
\hline & 50 & 52.6 & 1.242 & 0.9807 & 19.97 \\
\hline & 75 & 49.8 & 1.526 & 0.9957 & 11.72 \\
\hline
\end{tabular}

Table 4 Values of effective moisture diffusivity for oven drying of whole red pepper and bitter leaf slices

\begin{tabular}{c|ccc}
\hline Sample & Drying temperature $\left({ }^{\circ} \mathrm{C}\right)$ & $\begin{array}{c}\text { Effective moisture diffusivity } \\
D_{\text {eff }} \times 10^{-9}\left(\mathrm{~m}^{2} / \mathrm{s}\right)\end{array}$ & 0.8399 \\
& 35 & 15.69 & 0.9163 \\
\multirow{3}{*}{ Red Pepper } & 45 & 25.82 & 0.9191 \\
& 55 & 35.18 & 0.9545 \\
\hline \multirow{3}{*}{ Bitter Leaf } & 75 & 84.79 & 0.9417 \\
& 35 & 0.294 & 0.8590 \\
& 45 & 0.392 & 0.8783 \\
\hline
\end{tabular}



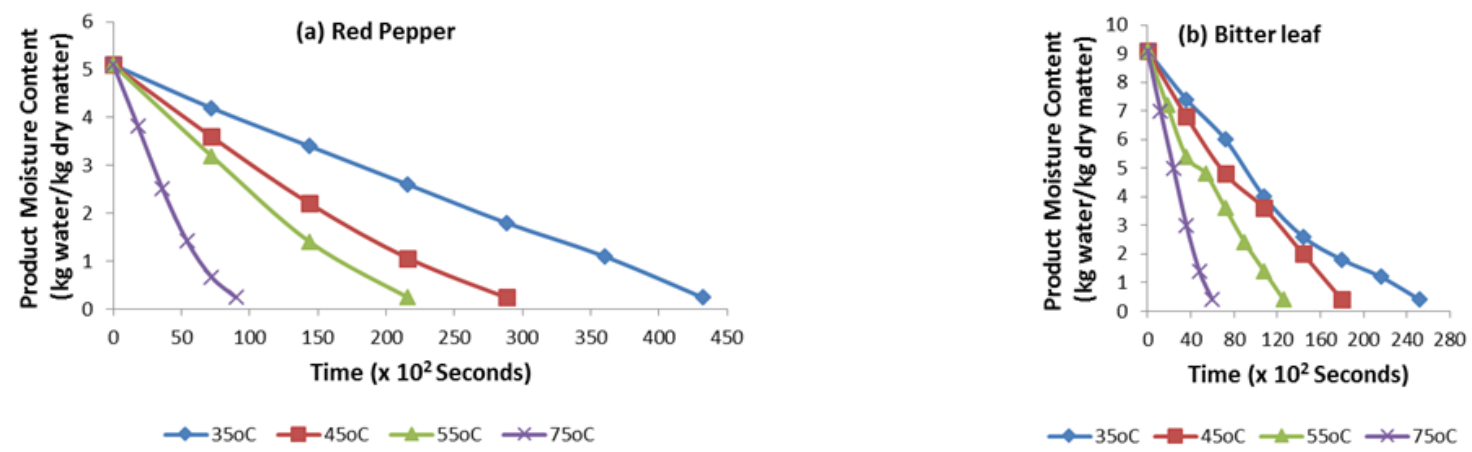

Figure 1 (a) Drying curves of whole red pepper at different temperature (b) Drying curves of bitter leaf slices at different temperature
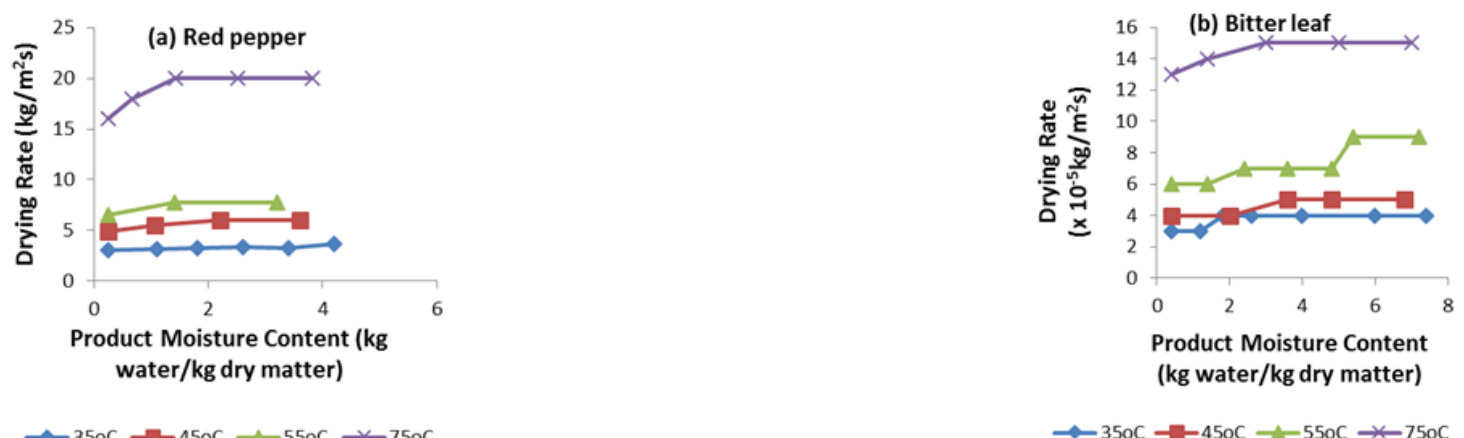

Figure 2 Variation of drying rates with product moisture content for (a) Red pepper (b) Bitter leaf

(a) $35^{\circ} \mathrm{C}$

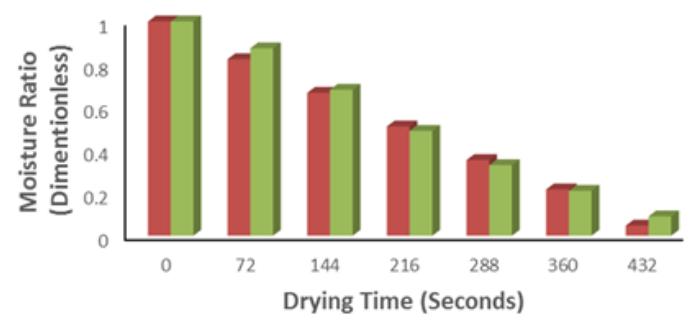

- Experimental Moisture Ratio $\quad$ - Predicted Moisture Ratio

(c) $55^{\circ} \mathrm{C}$

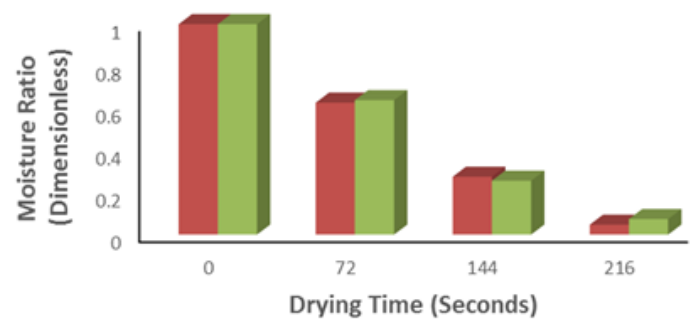

= Experimental Moisture Ratio = $=$ Predicted Moisture Ratio (b) $45^{\circ} \mathrm{C}$

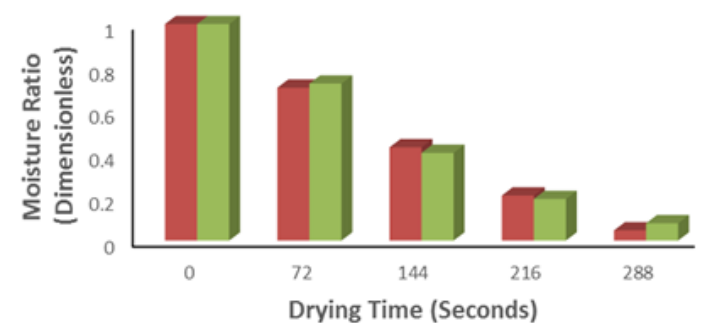

- Experimental Moisture Ratio $\quad$ Predicted Moisture Ratio

(d) $75^{\circ} \mathrm{C}$

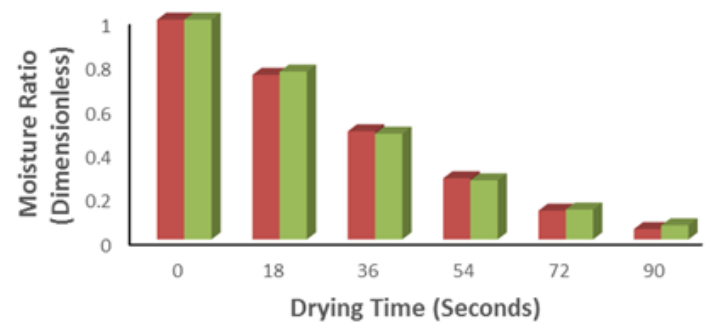

= Experimental Moisture Ratio = Predicted Moisture Ratio

Figure 3 Representation of predicted moisture ratio versus experimental moisture ratio for red pepper at (a) $35^{\circ} \mathrm{C}$ (b) $45^{\circ} \mathrm{C}$ (c) $55^{\circ} \mathrm{C}$ (d) $75^{\circ} \mathrm{C}$ 
Therefore, Eq. (14) is subject to the boundary condition

$$
\begin{aligned}
& \text { That at } Y=Y,-K \frac{\partial T}{\partial Y}=h_{r}\left(T_{R}-T_{P}\right) Y \\
& \text { At } Y=0,-K \frac{\partial T}{\partial Y}=m / A \lambda_{V} \frac{d x}{d t} \\
& \text { At } t=0, t=T=T_{0} \text { for all } Y
\end{aligned}
$$

The particular solutions of Eq. (14) are unknown for practical boundary condition (Kreith, 1965). Hence, with the aid of assumption number (1) and (2)

$$
\begin{aligned}
& q_{R}=h_{R}\left(T_{R}-T_{P}\right) \\
& q_{Y}=U_{Y}\left(T_{R}-T_{P}\right)
\end{aligned}
$$

Adding Eqs. (17) and (18)

$$
q_{R}+q_{Y}=q=\left(h_{R}+U_{Y}\right)\left(T_{r}-T_{p}\right)
$$

The heat flux due to the latent heat of vaporization from the feed is given by Eq. (16a)

$$
q=-K \frac{\partial T}{\partial Y}=m /_{A} \lambda_{V} \frac{d X}{d t}
$$

This equation is equal to Eq. (18)

$$
\begin{aligned}
& m / A \lambda_{V} \frac{d X}{d t}=\left(h_{R}+U_{Y}\right)\left(T_{r}-T_{P}\right) \\
& \int_{0}^{t} d t=\frac{m /{ }_{A} \lambda_{V}}{\left(h_{R}+U_{Y}\right)\left(T_{r}-T_{P}\right)} \int_{X_{b}}^{X_{a}} d X \\
& \left.t=\frac{(m / A}{\left(h_{R}+U_{Y}\right)\left(T_{r}-T_{P}\right)}\right)\left(X_{a}-X_{b}\right)
\end{aligned}
$$

From literature (Treybal, 1980),

$$
h_{R}=\sum \frac{\left[5.729 \times 10^{-8}\right]\left[T_{R}^{4}-T_{P}^{4}\right]}{T_{R}-T_{P}}
$$

Where $t=$ Drying time (seconds); $m / A=$ Mass of feed per unit area of drying tray $\left(\mathrm{kg} / \mathrm{m}^{2}\right) ; \lambda_{V}=$ Latent heat of moisture vapourisation $(\mathrm{kJ} / \mathrm{kg}) ; h_{R}=$ Radiation heat transfer coefficient $\left(\mathrm{w} / \mathrm{m} 2{ }^{\circ} \mathrm{C}\right) ; U_{Y}=$ Overall heat transfer coefficient due to conduction and radiation $\left(\mathrm{w} / \mathrm{m}^{2}{ }^{\circ} \mathrm{C}\right)$; $T_{R}=$ Temperature of hot radiating surface $\left({ }^{\circ} \mathrm{C}\right) ; T_{P}=$
Temperature of the feed $\left({ }^{\circ} \mathrm{C}\right) ; \sum=$ Emissivity of the drying surface; $5.729 \times 10^{-8}=$ Stefan-Boltzmann constant.

\section{Effective Moisture Diffusivity}

The moisture transport (water transfer) during whole red pepper and bitter leaf drying was described by applying the Fick's diffusion model. The experimental drying curves obtained at the different drying temperature respectively were adjusted to the Fick's diffusion equation (Eq. (11)). The good linear adjustment to this equation with coefficient of determination $\left(R^{2}\right)$ ranging from $84-95 \%$ for the drying process showed that drying of whole red pepper and sliced bitter leaf is respectively well represented by the diffusion model proposed by Fick and this allowed for the calculation of the effective moisture diffusivity $\left(D_{e f f}\right)$ at the different drying temperature. The results are presented in Table 4. The results show that the effective moisture diffusivity for unsliced whole red pepper and bitter leaf correspondingly ranged from 15.69 to $84.79 \times 10^{-9} \mathrm{~m}^{2} / \mathrm{s}$ and 0.294 to 1.263 $\mathrm{x} 10^{-9} \mathrm{~m}^{2} / \mathrm{s}$ for a temperature range of 35 to $75^{\circ} \mathrm{C}$. These values are within the general range of $10^{-11}$ to $10^{-9} \mathrm{~m}^{2} / \mathrm{s}$ for drying of food materials (Sacilik and Elicin, 2006; Doymaz, 2007; Honoŕe et al., 2014; Lemus-Mondaca et al., 2015). The results in Table 4 showed that irrespective of the vegetable type, effective moisture diffusivity increased with increase in drying temperature. Similar observations have been reported for increase in diffusivity coefficient as air drying temperature increased (Kadam et al., 2011; Khawas et al., 2014).

The activation energy and the Arrhenius constant were determined from the slope and the y-intercept, of the plot of $\ln D_{\text {eff }}$ vst $1 / T_{a b s}$ (Figure 5), respectively, and the values are presented in Table 5.

The Arrhenius constant is a diffusivity constant equivalent to the diffusivity at infinitely high temperature. Activation energy is the energy barrier that must be overcome in order to activate moisture diffusion. By increasing the temperature and thus the drying rate this energy barrier can be easily overcome, however, there should be a compromise between high temperature and acceptable product quality (Kashaninejad et al., 2007; Hii et al., 2009). The values of $D_{0}$ and $E_{a}$ were estimated at $0.0309 \mathrm{~m}^{2} / \mathrm{s}$ and $37.11 \mathrm{~kJ} / \mathrm{mol}$ for un-sliced whole red pepper as well as $0.0001 \mathrm{~m}^{2} / \mathrm{s}$ and $32.86 \mathrm{~kJ} / \mathrm{mol}$ for sliced bitter leaf, respectively. Activation energy values lie from 12.7 to $110 \mathrm{~kJ} / \mathrm{mol}$ for most food material (Afolabi and Agarry, 2014). The values obtained in this present work lies within the stated range and also compares relatively with the value of $12.32-14.34 \mathrm{~kJ} / \mathrm{mol}$ obtained for potato by Senadeera et al. (2003), $19.96 \mathrm{~kJ} / \mathrm{mol}$ for red apple (Kaya et al., 2007), and 16.749 and $22.437 \mathrm{~kJ} / \mathrm{mol}$ for treated and untreated okra (Sobukola, 2009), respectively. 
Table 5 Arrhenius constant and Activation energy of whole red pepper and bitter leaf slices

\begin{tabular}{rccc}
\hline Sample & Arrhenius constant $D_{0}\left(\mathrm{~m}^{2} / \mathrm{s}\right)$ & Activation energy $E_{0} \mathrm{~kJ} / \mathrm{mol}$ & $R^{2}$ \\
\hline Red Pepper & 0.0309 & 37.11 & 0.9947 \\
Bitter Leaf & 0.0001 & 32.86 & 0.9861 \\
\hline
\end{tabular}

(a) $35^{\circ} \mathrm{C}$

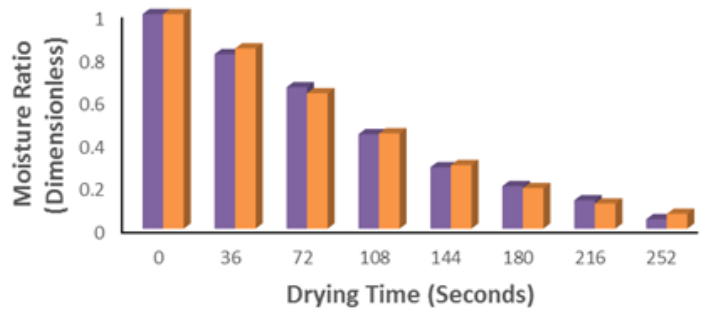

Experimental Moisture Ratio a Predicted Moisture Ratio

(c) $55^{\circ} \mathrm{C}$

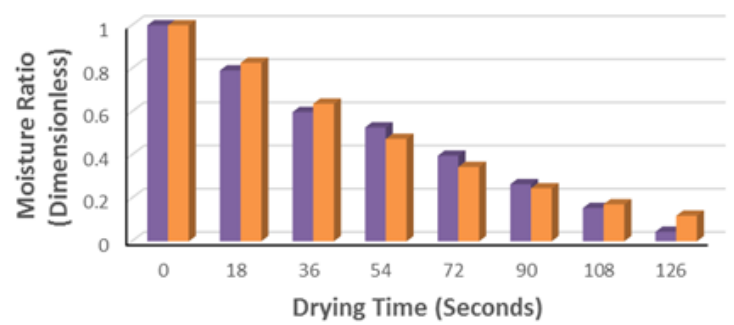

Experimental Moisture Ratio $\quad$ Preicted Moisture Ratio (b) $45^{\circ} \mathrm{C}$

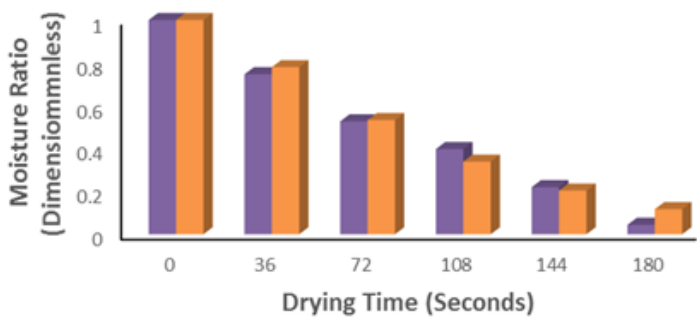

- Experimental Moisture Ratio $\quad$ Predicted Moisture Ratio

(d) $75^{\circ} \mathrm{C}$

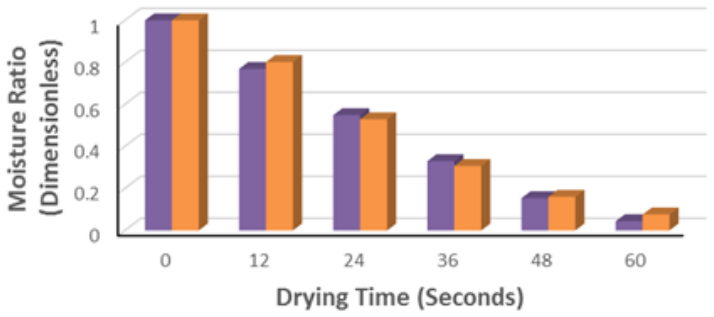

Experimental Moisture Ratio = Predicted Moisture Ratio

Figure 4 Representation of predicted moisture ratio versus experimental moisture ratio for bitter leaf at (a) $35^{\circ} \mathrm{C}$ (b) $45^{\circ} \mathrm{C}$ (c) $55^{\circ} \mathrm{C}$ (d) $75^{\circ} \mathrm{C}$

\section{Conclusion}

From the results of the investigation of the drying characteristics of red pepper and bitter leaf, it can be concluded that drying rates and thus drying times were affected by drying temperature under oven drying. The drying time required to attain a final product moisture content of $4 \%$ and $5 \%$ for bitter leaf and red pepper, respectively, decrease with increase in temperature. The drying rate of red pepper and bitter leaf is respectively proportional to drying temperature and inversely proportional to drying time while the drying of red pepper and bitter leaf is respectively both in constant rate and falling rate period, hence they are hygroscopic and thus behave like porous solids.

By using the semi empirical Page model, sufficient description of the drying curves of red pepper and bitter leaf under oven drying could be obtained and this could represent a useful tool for engineering purposes. The Fick's diffusion model showed a good linear adjustment to the experimental results obtained under oven drying which allowed the estimation of the effective moisture diffusivity. The estimated effective moisture diffusivities ranged from 15.69 to $84.79 \times 10^{-9} \mathrm{~m}^{2} / \mathrm{s}$ for un-sliced red pepper and 0.294 to $1.263 \times 10^{-9} \mathrm{~m}^{2} / \mathrm{s}$ for bitter leaf for a temperature range of 35 to $75^{\circ} \mathrm{C}$, respectively. The effective moisture diffusivities increased with drying temperature following the Arrhenius type relationship.
The values for $D_{0}$ and $E_{a}$ were estimated at $0.0309 \mathrm{~m}^{2} / \mathrm{s}$ and $37.11 \mathrm{~kJ} / \mathrm{mol}$ for un-sliced red pepper and 0.0001 $\mathrm{m}^{2} / \mathrm{s}$ and $32.86 \mathrm{~kJ} / \mathrm{mol}$ for sliced bitter leaf, respectively.

\section{References}

Afolabi TJ, Agarry SE. 2014. Mathematical modelling and simulation of the mass and heat transfer of batch convective air drying of tropical fruits. Chemical and Process Engineering Research, 12: 9-18.

Agarry SE, Durojaiye AO, Afolabi TJ. 2005. Effect of pretreatment on the drying rates and drying time of potato. Journal of Food Technology, 3 (3): 361-364.

Agarry SE, Yusuf RO, Owabor CN. 2006. Studies on air-dry processing of onions (Alium cepa). Journal of Food Technology, 4 (4): 357-361.

Agarry SE, Aworanti OA. 2012. Modelling the drying characteristics of osmosised coconut strips at constant air temperature. J. Food Proc. Technol., 3:151.

Agarry SE, Owabor CN. 2012. Modelling of the drying kinetics of banana under natural convection and forced air drying. Journal of Nigerian Society of Chemical Engineers 27 (1): 101 - 115.

Akpinar E, Midilli A, Bicer Y. 2003. Single layer drying behavior of potato slices in a convective cyclone dryer and mathematical modeling. Energy Conversion Management 44: 1689 - 1705.

Akpinar EK, Bicer Y. 2008. Mathematical modeling of thin layer drying process of long green pepper in solar dryer and under open sun. Energy Conversion and Management 49: 1367-1375.

Arslan D, Özcan MM. 2010. Study the effect of sun, oven and microwave drying on quality of onion slices. LWT - Food Science and Technology 43: 1121-1127. 
Association of Official Analytical Chemists, 1995. Official Methods of Analysis, $15^{\text {th }}$ edition, AOAC, 930.06, Arlington, Va. USA.

Audu TO. 1995. Chemical Engineering what future for Nigeria? Being an Inaugural Lecture Series 38 delivered in University of Benin, Benin-City.

Barnell HB. 1974. Biology and the food industry "in the Institute of Biology's Studies in Biology No. 45. Edward Arnold Publishers Limited, London W1 x 8LL.

Crank J. 1975. The mathematics of diffusion, $2^{\text {nd }}$ ed., Oxford, London.

Demir V, Gunhan T, Yagcioglu AK, Degirmencioglu A. 2004 Mathematical modeling and the determination of some quality parameters of air-dried bay leaves. Biosystem Engineering, 88: $325-335$.

Doymaz I. 2005. Drying characteristics and kinetics of okra. Journal of Food Engineering, 69: 275 - 279.

Doymaz I. 2007. Air-drying characteristics of tomatoes. Journal of Food Engineering, 78 (4): 1291 - 1297.

Doymaz I. 2011. Drying of green bean and okra under solar energy. Chemical Industry and Chemical Engineering Quarterly, 17 (2): 199-205.

Ertekin C, Yaldiz O. 2004. Drying of eggplant and selection of a suitable thin layer drying model. Journal of Food Engineering, 3: $349-359$.

Feng H, Tang J, Dixon-Warren I. 2000. Determination of moisture diffusivity of red delicious apple tissues by thermogravimetric analysis. Drying Technology, 18 (6): 1183 -1199.

Hii CL, Law CL, Cloke M. 2009. Modeling using a new thin layer drying model and product quality of cocoa. Journal of Food Engineering, 90: $191-198$.

Honoré O, François Z, Raguilignaba S, Aboubacar T, Hélène D. 2014. Characterization of Okra Convective Drying, Influence of Maturity. Food and Nutrition Sciences, 5: 590-597.

Ihekoronye AI, Ngoddy PO. 1985. Integrated Food Science and Technology for the Tropics, Macmillan publishers, London.

Ismail MA, Ibn Idriss EM. 2013. Mathematical modelling of thin layer solar drying of whole okra (Abelmoschosus esculentus (L.). Moench) pods. International Food Research Journal, 20 (4): $1983-1989$.

Kadam DM, Goyal RK, Singh KK, Gupta MK. 2011. Thin layer convective drying of mint leaves. Journal of Medicinal Plant Research, 5 (2): 164-170.

Karim MA, Hawlader MNA. 2005. Mathematical modelling and experimental investigation of tropical fruits drying. International Journal of Heat and Mass Transfer, 48: 4914 4925.

Kashaninejad M, Mortazavi A, Safekordi A, Tabil LG. 2007. Thin layer characteristics and modelling of pistachio nuts. Journal of Food Engineering, 78: 98-108.

Kaya A, Aydin O, Demirtas C. 2007. Drying kinetics of red delicious apple. Biosystems Engineering 96 (4): 517-524.

Khawas P, Das AJ, Dash KK, Deka SC. 2014. Thin-layer drying characteristics of Kachkal banana peel (Musa ABB) of Assam, India. International Food Research Journal, 21 (3): 975 - 982.
Kingsly RP, Goyal RJ, Manikantan MR, Ilyas SM. 2007. Effects of pretreatments and drying air temperature on drying behaviour of peach slice. International Journal of Food science and Technology, 42: 65 -69.

Kreith F. 1965. Principles of Heat Transfer, $2^{\text {nd }}$ Edition, International Textbook Company.

Lemus-Mondaca R, Vega-Gálvez A, Moraga NO, Astudillo S. 2015. Dehydration of Stevia rebaudiana Bertoni Leaves: Kinetics, Modeling and Energy Features. Journal of Food Processing and Preservation, 39: 508-520. doi: $10.1111 /$ jfpp. 12256

Maudkordylas J. 1990. Processing and Preservation of Tropical and Subtropical Foods. $1^{\text {st }}$ ed. Published by Macmillan Education Limited, London.

Nguyen TA, Verboven P, Daudin JD, Nicolai BM. 2004. Measurement and modeling of water sorption isotherms of conference pear flesh tissue in the high humidity range. Postharvest Biology and Technology, 33: 229 - 241.

Ochoa-Marinez CI, Ayala-Aponte AA. 2009. Suitability of Crank's solution to Ficks second law for water diffusivity calculation and moisture loss prediction in osmotic dehydration of fruits. Journal of Food Process Engineering, 32 (6): 933 - 943.

Pala M, Mahmutoglu T, Saygi B. 1996. Effects of pretreatments on the quality of open air and solar dried products. Food, 40: 137 141.

Park KJ, Vohnikova Z, ReisBrod FP. 2002. Evaluation of drying parameters and desorption isotherms of garden mint leaves (Mentha crispa L.). Journal of Food Engineering, 51: 193 - 199.

Sacilik K, Elicin AK. 2006. The thin layer drying characteristics of organic apple slices. Journal of Food Engineering, 73(3): $281-$ 289.

Senadeera W, Bhandari BR, Young G, Wijesinghe B. 2003. Influence of shapes of selected vegetable materials on drying kinetics during fluidized bed drying. Journal of Food Engineering, 58: 277-283.

Simal S, Garau C, Femenia A, Rossello C. 2005. Drying of red pepper (Capsicum annum): water desorption and quality. International Journal of Food Engineering, 1(4): 1 -14.

Sobukola O. 2009. Effect of pretreatment on the drying characteristics and kinetics of okra (Abelmoschus esculentus (L.) Moench) slices. International of Journal of Food Engineering 5 (2) ISSN online 1556 - 3758, DOI: 10.2202/1556-3758.1191.

Treybal RE. 1980. "Mass Transfer Operations" $3^{\text {rd }}$ Edition, MaGraw Hill, Book Coy. London.

Waewsak J, Chindaruksa S, Punlek C. 2006. A mathematical modeling study of hot air drying for some agricultural products. Thammasat International Journal of Science and Technology, 11: $14-20$.

Yaldiz O, Ertekin C, Uzun HB. 2001. Mathematical modelling of thin layer solar drying of sultana grapes. Energy, 26: 457-465. 